\title{
Porównanie stężenia fluorków w kościach człowieka, psa, lisa i jenota zamieszkujących północno-zachodnią Polskę *
}

\section{Comparison of fluoride concentrations in human, dog, fox and raccoon dog bones from northwestern Poland}

\author{
Mirona Palczewska-Komsa \\ Katedra i Zakład Biologii i Parazytologii Medycznej Pomorskiego Uniwersytetu Medycznego w Szczecinie \\ al. Powstańców Wlkp. 72, 70-111 Szczecin \\ Kierownik: prof. dr hab. n. biol. Elżbieta Kalisińska
}

\begin{abstract}
SUMMARY
Introduction: Since the beginning of the $\mathrm{XX}^{\text {th }}$ there has been a constant increase in fluoride $\left(\mathrm{F}^{-}\right)$emissions into the environment, mainly due to the development of industry, the fluoridation of drinking water, and the widespread use of toothpaste containing fluoride. All these factors have resulted in an intensive accumulation of $\mathrm{F}^{-}$in the bodies of vertebrates, mainly in their bones. It is therefore reasonable to estimate the $\mathrm{F}^{-}$concentration in humans and other long-lived mammals. Accordingly, ecotoxicologists worldwide have looked for mammalian species that may serve as good bioindicators of environmental fluoride pollution. In contrast to ungulates, long-lived domestic mammals and wild carnivores have rarely been used for this purpose (including the dog, fox and raccoon dog).

The main aims of this study were to: 1 ) investigate $\mathrm{F}^{-}$concentrations in bones obtained from humans, dog, fox and raccoon dog from northwestern Poland, 2) perform intra- and inter-specific comparisons of $\mathrm{F}^{-}$concentrations in the studied mammalian bones against the background of environmental and living conditions, 3) examine the relationship between concentrations of $\mathrm{F}^{-}$ in bones and the age or age category of the studied mammals. Material and methods: The study material comprised bones of the hip joint obtained from 36 patients who underwent hip
\end{abstract}

replacement in Szczecin, 43 dogs from Szczecin veterinary clinics, 32 foxes and 18 raccoon dogs provided by hunters, with the whole test material consisting of 129 samples. The indications of $\mathrm{F}^{-}$(using potentiometry with Thermo Orion ion-selective electrodes) were performed in triplicate. The $\mathrm{F}^{-}$concentration was expressed on a dry weight basis.

Results: Interspecific analysis showed that the largest number of differences in the concentrations of $\mathrm{F}^{-}$were between the fox and raccoon, and then between the dog and fox, and then between the dog and the wild canids (foxes and raccoon dogs together). Close statistically significant differences were also found between the samples from humans and the fox, and also between human and dog bones. There were no statistically significant differences in the concentrations of $\mathrm{F}^{-}$between humans and raccoons, humans and canids (dog, fox, raccoon dog together), and between dogs and raccoon dogs.

Conclusions: Domesticated and wild canids are good bioindicators of environmental levels of fluoride, because they reflect the concentration of fluoride in bones observed in humans who lived in a similar area.

Key words: fluoride, humans, animals, bone tissue.

Głównymi celami pracy było: 1) poznanie stężeń $\mathrm{F}^{-} \mathrm{w}$ kościach uzyskanych od człowieka, psa, lisa i jenota pochodzących z północno-zachodniej Polski; 2) dokonanie porównań wewnątrzi międzygatunkowych wartości stężenia $\mathrm{F}^{-}$w próbkach kostnych badanych ssaków na tle warunków bytowo-środowiskowych; 3) zbadanie związków między stężeniami $\mathrm{F}^{-} \mathrm{w}$ kościach a wiekiem lub kategorią wiekową analizowanych ssaków.

Materiał i metody: Materiał do badań stanowiły kości współtworzące staw biodrowy, pochodzące od 36 pacjentów po alloplastyce stawu biodrowego, 43 psów ze szczecińskich lecznic oraz 32 lisów i 18 jenotów dostarczonych przez myśliwych. Całość materiału badawczego obejmowała 129 próbek, a oznaczenia $\mathrm{F}^{-}$(metodą potencjometryczną z wykorzystaniem jonoselektywnej elektrody Thermo Orion) wykonano w 3 powtórzeniach. Stężenie $\mathrm{F}^{-}$wyrażono w przeliczeniu na suchą masę.

* Zwięzła wersja rozprawy doktorskiej przyjętej przez Radę Wydziału Lekarsko-Biotechnologicznego i Medycyny Laboratoryjnej Pomorskiego Uniwersytetu Medycznego w Szczecinie. Promotor: prof. dr hab. n. biol. Elżbieta Kalisińska, promotor pomocniczy: dr hab. n. med. Danuta Kosik-Bogacka. Oryginał obejmuje 160 stron, 17 tabel, 17 rycin i 234 pozycje wykorzystanego piśmiennictwa. Rozprawa doktorska została sfinansowana z projektu badawczego PUM 25/11/PB. 
Wyniki: Analiza międzygatunkowa wykazała, że najwięcej różnic w stężeniu $\mathrm{F}^{-} \mathrm{w}$ materiale kostnym odnotowano między lisem i jenotem, a następnie między psem i lisem oraz psem i dzikimi psowatymi (lis i jenot łącznie). Bliskie istotności statystycznej różnice $\mathrm{w}$ koncentracji $\mathrm{F}^{-}$zaznaczyły się między próbkami kostnymi człowieka i lisa oraz człowieka i psa. W przypadku człowieka i jenota, człowieka i poszczególnych gatunków psowatych (pies, lis, jenot łącznie) oraz psa i jenota

\section{WSTĘP}

Stała emisja fluorków do środowiska, zarówno naturalna, jak i antropogeniczna (na skutek rozwoju przemysłu oraz powszechnego stosowania związków fluoru w medycynie, stomatologii i profilaktyce dentystycznej), stwarza niebezpieczeństwo intoksykacji tym pierwiastkiem ssaków, w tym również człowieka. Począwszy od XX w., w każdej dekadzie podaż fluorków antropogenicznego pochodzenia zwiększała się w środowisku dwukrotnie. W związku z tym uzasadnione jest kontrolowanie stężeń fluoru u ludzi i innych długowiecznych ssaków.

W badaniach biomonitoringowych i bioindykacyjnych istotnym kierunkiem jest oznaczenie stężeń fluorków w organizmach żywych. Wśród różnych rodzajów materiałów biologicznych w ocenie ryzyka narażenia na fluorki coraz większe znaczenie przypisuje się tkankom zmineralizowanym, głównie kościom, ponieważ ze względu na ich okresowy wzrost i ciągłą przebudowę są one dobrym materiałem do badań długoterminowych kumulacji fluorków.

Od dawna trwają poszukiwania gatunków zwierząt, które mogą służyć jako bioindykatory m.in. zanieczyszczenia środowiska fluorkami. W pracach naukowych dotyczących wpływu fluorków na organizm człowieka wykorzystuje się inne gatunki ssaków jako zwierzęta modelowe. Najczęściej są to myszy i szczury, których biologiczna długość życia wynosi nie więcej niż 2-5 lat. W pośredniej ocenie zagrożenia środowiska związkami fluoru bardziej odpowiednie są średniej wielkości wszystkożerne ssaki, gdyż tempo metabolizmu, dieta i długość życia czynią je bardziej zbliżonymi pod tymi względami do człowieka niż drobne i krótko żyjące gryzonie. Przykładem takich zwierząt są ssaki z rodziny psowatych (Canidae): pies domowy (Canis lupusf. familiaris), lis (Vulpes vulpes) i jenot (Nyctereutes procyonoides). W Polsce są to wszystkożerne ssaki drapieżne, pospolicie występujące i zajmujące określony obszar przez cały rok, co predysponuje je do bycia potencjalnie dobrymi bioindykatorami w pośredniej ocenie zanieczyszczenia środowiska fluorkami. Dotychczas w Europie psowate były jedynie sporadycznie wykorzystywane do celów bioindykacyjnych w podanym zakresie. Na podstawie wyników badań własnych dotyczących stężenia fluorków w zębach lisa stwierdzono, że gatunek ten jest dobrym bioindykatorem w badaniach środowiskowych $[1,2]$.

Do tej pory nie przeprowadzano analiz porównawczych koncentracji fluorków w kościach ssaków żyjących w Polsce w okresie celowej fluoryzacji wody i po jej zaprzestaniu (po 1996 r.). Nieliczne są doniesienia na temat stężenia fluorków nie odnotowano istotnych statystycznie różnic w stężeniu $\mathrm{F}^{-}$ w ich kościach.

Wnioski: Stwierdzono, że udomowione i dziko żyjące psowate są dobrymi bioindykatorami zanieczyszczenia środowiska fluorkami, bowiem odzwierciedlają one koncentrację fluorków w kościach obserwowaną u człowieka żyjącego na podobnym obszarze.

Słowa kluczowe: związki fluoru, ludzie, zwierzęta, tkanka kostna.

w elementach twardych pochodzących od ludzi narażonych na wpływ czynników środowiskowych pobranych śródoperacyjnie podczas zabiegu alloplastyki.

Wyniki przeprowadzonych badań mogą przyczynić się do poszerzenia wiedzy na temat stopnia obciążenia środowiska ożywionego i nieożywionego związkami fluoru, jak również pomogą ocenić ewentualną przydatność psowatych do celów bioindykacyjnych. Niniejsza praca jest kontynuacją studiów bioindykacyjnych prowadzonych w Katedrze i Zakładzie Biologii i Parazytologii Medycznej Pomorskiego Uniwersytetu Medycznego w Szczecinie (PUM).

\section{CELE I HIPOTEZY PRACY}

Głównym celem pracy było:

1. Poznanie stężeń fluorków w kościach uzyskanych od człowieka, psa, lisa i jenota pochodzących z północno-zachodniej Polski.

2. Porównanie stężenia fluorków w kościach badanych ssaków na tle warunków bytowo-środowiskowych.

3. Określenie przypuszczalnie istniejących związków między stężeniami fluorków w kościach a wiekiem lub kategorią wiekową analizowanych ssaków.

Sformułowano cztery hipotezy badawcze:

1. Ze względu na suplementację diety oraz wykorzystywanie preparatów do higieny jamy ustnej zawierających związki fluoru większe stężenia fluorków występują u człowieka i psa żyjących w podobnych warunkach w porównaniu do dzikich psowatych zamieszkujących głównie obszary pozamiejskie.

2. Kości osobników starszych badanych gatunków ssaków w porównaniu do młodszych cechują się większym stężeniem fluorków.

3. W materiale kostnym pochodzącym od badanych gatunków (uwzględniając ich wiek) kolejność stężenia fluorków powinna mieć następujący układ: człowiek > pies > lis = jenot.

4. Udomowione i dziko żyjące psowate są dobrymi bioindykatorami zanieczyszczenia środowiska fluorkami.

\section{MATERIAŁ I METODY}

\section{Materiat}

Materiał do badań stanowiły elementy kostne wchodzące w skład stawu biodrowego człowieka i trzech gatunków dziko żyjących ssaków należących do rodziny psowatych: udomowionego psa, lisa i jenota. Łącznie zgromadzono 129 próbek 
TABELA 1. Zestawienie ilości próbek zgromadzonego materiału badawczego

\begin{tabular}{lc}
\multicolumn{1}{c}{ Gatunek } & $\begin{array}{c}\text { Liczba zgromadzonych } \\
\text { próbek materiału kostnego }\end{array}$ \\
\hline Człowiek (Homo sapiens) & 36 \\
\hline Pies (Canis lupus f. familiaris) & 43 \\
\hline Lis (Vulpes vulpes) & 32 \\
\hline Jenot (Nyctereutes procynoides) & 18 \\
\hline Razem & 129 \\
\hline
\end{tabular}

materiału kostnego, w tym 36 próbek pochodzenia ludzkiego i 93 próbki pochodzenia zwierzęcego (tab. 1).

Grupę badaną stanowiło 36 pacjentów z północno-zachodniej Polski hospitalizowanych w Klinice Ortopedii i Traumatologii Pomorskiej Akademii Medycznej w Szczecinie w 2009 r. (obecnie Pomorski Uniwersytet Medyczny w Szczecinie). Byli oni mieszkańcami: Barlinka $(n=1)$, Bińca $(n=1)$, Chojny $(n=1)$, Goleniowa ( $n=2)$, Kamienia Pomorskiego ( $n=1)$, Luchowa Górnego $(n=1)$, Nowego Warpna $(n=1)$, Pniewa $(n=1)$, Stargardu Szczecińskiego $(n=1)$ i Szczecina $(n=26)$. Do dalszych analiz podzielono pacjentów ze względu na miejsce zamieszkania na dwie grupy: Szczecin $(n=26)$ i inne miejscowości województwa zachodniopomorskiego $(\mathrm{n}=10)$. Wszyscy pacjenci byli poddani alloplastyce głowy kości udowej stawu biodrowego. Najczęstszym wskazaniem do tego zabiegu było zwyrodnienie lewego i/lub prawego stawu biodrowego oraz złamanie szyjki kości udowej lewej. Alloplastyka umożliwiała pozyskanie fragmentów usuwanych kości w ilości wystarczającej do zaplanowanych badań, bez narażania pacjentów na dodatkowe obciążenia. Na przeprowadzenie badań uzyskano Zgodę Komisji Bioetycznej PUM (KB-0012/115/11).

Kości udowe i piszczelowe uzyskane od psów gromadzono przy współudziale lekarzy weterynarii. Psy pochodziły z lecznicy Schroniska dla Bezdomnych Zwierząt w Szczecinie oraz lecznicy Towarzystwa Opieki nad Zwierzętami (oddział w Szczecinie). Główną przyczyną eutanazji były schorzenia układu oddechowego, naczyniowego i choroby nowotworowe. Psy nie były celowo usypiane do tych badań. Na pozyskiwanie materiału biologicznego od psów uzyskano zgodę Powiatowego Lekarza Weterynarii w Szczecinie. Natomiast kości udowe i piszczelowe pochodzące od lisa i jenota uzyskano w większości od okazów upolowanych przez myśliwych zgodnie z przepisami określonymi w Rozporządzeniu Ministra Środowiska z 16 marca 2005 r. w sprawie okresów polowań na zwierzęta łowne (Dz.U. 2005, nr 48, poz. 459). Część osobników stanowiły zwierzęta, które zginęły na drogach w wyniku kolizji z samochodami na obrzeżach Szczecina. Na badania materiału biologicznego pochodzącego od martwych zwierząt stosowny dokument wydała Lokalna Komisja Etyczna do Badań na Zwierzętach (Uchwała nr 5/2012 z 5.12.2012 r.), aczkolwiek na tego rodzaju badania zgoda nie jest wymagana.

W latach 2009-2012 zgromadzono łącznie 32 młode i dorosłe psy (Canis lupus f. familiaris) z terenu Szczecina. Wśród nich znajdowało się 13 samic i 19 samców. Przebadano także materiał pochodzący od jednodniowych szczeniąt ( $n=11$ ), w tym odpowiednio osobników płci męskiej $(n=5)$ i osobników płci żeńskiej $(n=6)$.
Grupę badanych lisów stanowiły łącznie 32 okazy (15 samców i 17 samic), które pochodziły z obszaru północno-zachodniej Polski: z okolic Szczecina ( $=6$ ), Bań ( $n=5)$, Stargardu Szczecińskiego ( $n=4)$, Gryfic ( $n=1)$, Choszczna $(n=6)$, Myśliborza ( $n=2)$ i Kamienia Pomorskiego ( $n=1)$; część osobników pochodziła z Wojewódzkiego Inspektoratu Weterynarii w Szczecinie ( $n=7)$, ale ich pochodzenie nie jest znane. Do dalszych analiz lisy podzielono ze względu na ich pochodzenie na dwie grupy: lisy ze Szczecina i jego okolic (Szczecin, Stargard Szczeciński; $\mathrm{n}=10$ ) i lisy z południowej części województwa zachodniopomorskiego (Banie, Choszczno, Myślibórz; $n=13$ ), natomiast pozostałe lisy $(n=9)$ nie zostały objęte analizą. Lisy zostały zgromadzone w trzech sezonach łowieckich (2008/2009, 2011/2012 i 2012/2013).

Wśród 18 jenotów znajdowało się 10 samców i 8 samic. Zwierzęta pochodziły z obszaru dwóch województw: 4 lisy z województwa zachodniopomorskiego - Szczecin $(n=3)$ i Leśno Górne $(\mathrm{n}=1)$ oraz 14 lisów z województwa lubuskiego - Bogdaniec $(n=2)$, Chyrzyno $(n=6)$ i Kostrzyn $(n=6)$ z sezonu łowieckiego 2009/2010, 2011/2012 i 2012/2013.

\section{Określenie wieku badanych osób i psowatych}

Wyodrębniono dwie kategorie wiekowe pacjentów: Hs1 - osoby poniżej 65. roku życia (r.ż.) i Hs2 - osoby powyżej 65. r.ż. (tab. 2).

Wiek psów określili lekarze weterynarii na podstawie informacji zawartych w dokumentacji medycznej oraz pochodzącej od właścicieli.

Psy $(n=43)$ podzielono na dwie kategorie wiekowe: C.l.f.o jednodniowe szczenięta $(n=11)$, C.l.f.1 - poniżej 2 lat $(n=4)$ oraz C.l.f.2 - powyżej 2 lat $(\mathrm{n}=28)$.

TABELA 2. Liczebność próbek kości z uwzględnieniem rozkładu płciowego i wiekowego pacjentów (Hs1 i Hs2)

\begin{tabular}{lccc}
\multirow{2}{*}{ Płeć } & \multicolumn{2}{c}{ Grupa wiekowa } & \multirow{2}{*}{ Razem } \\
\cline { 2 - 3 } & Hs1 (<65. r.ż.) & Hs2 (>65. r.ż.) & \\
\hline Mężczyźni & 8 & 5 & 13 \\
\hline Kobiety & 6 & 17 & 23 \\
\hline Łącznie & 14 & 22 & 36 \\
\hline
\end{tabular}

TABELA 3. Zestawienie liczby próbek kostnych pochodzących od psa, lisa i jenota $z$ uwzględnieniem płci i kategorii wiekowych

\begin{tabular}{|c|c|c|c|c|}
\hline \multirow{2}{*}{ Gatunek } & \multirow{2}{*}{$\begin{array}{c}\text { Grupa } \\
\text { wiekowa }\end{array}$} & \multicolumn{3}{|c|}{ Liczebność } \\
\hline & & $F$ & $M$ & $F+M$ \\
\hline \multirow{4}{*}{$\begin{array}{l}\text { Pies (Canis lupus } f \text {. } \\
\text { familiaris) }\end{array}$} & C.I.f.0 & 6 & 5 & 11 \\
\hline & C.I.f.1 & 3 & 5 & 8 \\
\hline & C.l.f.2 & 10 & 14 & 24 \\
\hline & razem & 19 & 24 & 43 \\
\hline \multirow{3}{*}{ Lis (Vulpes vulpes) } & $\mathrm{imm}$ & 10 & 6 & 16 \\
\hline & $\mathrm{ad}$ & 7 & 9 & 16 \\
\hline & razem & 17 & 15 & 32 \\
\hline \multirow{3}{*}{$\begin{array}{l}\text { Jenot (Nyctereutes } \\
\text { procynoides) }\end{array}$} & $\mathrm{imm}$ & 4 & 4 & 8 \\
\hline & ad & 4 & 6 & 10 \\
\hline & razem & 8 & 10 & 18 \\
\hline
\end{tabular}

F- samica; M - samiec; C.l.f.o - jednodniowe szczenięta psów; C.l.f.1 - psy <2 lat; C.l.f.2 - psy >2 lat; imm - osobnik młody; ad - osobnik dorosły 
Przy zakwalifikowaniu poszczególnych okazów lisa do jednej z dwóch kategorii wiekowej (młode immaturus lub dorosłe adultus) wykorzystano pomiary kłów zgodnie z pracą Knowlton i Whittemore [3].

Jenoty $(n=18)$ podzielono na dwie grupy wiekowe na podstawie masy ciała i wyglądu zębów (tab. 3). Za osobniki młode uznano okazy ważące poniżej 4,5 kg, a za dorosłe powyżej 4,5 kg [4].

Łącznie od psowatych do analizy chemicznej uzyskano 93 próbki.

\section{Przygotowanie próbek do analiz chemicznych}

Pobrane do badań kości udowe oczyszczono z resztek ścięgien i mięśni, a następnie zamrożone próbki przechowywano w temp. $-20^{\circ} \mathrm{C}$ do czasu analiz. Po rozmrożeniu oddzielono istotę zbitą i gąbczastą kości. Do dalszych analiz użyto istotę zbitą. Próbki suszono do stałej masy w suszarce laboratoryjnej w temp. $105^{\circ} \mathrm{C}$. Procentową zawartość wody w próbkach ustalono metodą wagową. Wysuszone próbki rozdrabniano w moździerzu agatowym. Każdą próbkę (o masie $1 \mathrm{~g}$ ) zważono z dokładnością do 0,0001 g na wadze analitycznej Sartorius YPDo3 - OCE. Ten etap prac wykonano w Katedrze i Zakładzie Biologii i Parazytologii PUM.

Kolejny etap analiz wykonano w Katedrze i Zakładzie Biochemii i Chemii Medycznej PUM. Odważone próbki zalewano $1 \mathrm{~mL}$ kwasu nadchlorowego i wytrząsano w temp. $90^{\circ} \mathrm{C}$ przez 1 godz. Po wystudzeniu, 0,5 mL próbki przenoszono do plastikowej probówki, a następnie dodawano $2 \mathrm{~mL}$ roztworu cytrynianu sodowego i 2,5 mL roztworu TISAB II. Roztwory odczynników przygotowano na bazie wysoko oczyszczonej wody (Pure Lab Option Elga).

\section{Oznaczenie fluorków w materiale kostnym}

Oznaczenie stężenia fluorków wykonano metodą potencjometryczną z wykorzystaniem jonoselektywnej elektrody Thermo Orion (Thermo Scientific, USA). Zawartość fluorków w próbce obliczono na podstawie różnicy potencjałów mierzonych w każdej próbce, masy próbki oraz stężenia dodanego wzorca. Po wymieszaniu, w każdej próbce przez 10 min mierzono potencjał - 5 min przed dodaniem odpowiedniego wzorca i 5 min po jego dodaniu.

Poprawność procedury analitycznej kontrolowano poprzez oznaczanie stężenia jonów fluorkowych w materiałach o znanych stężeniach, tj. wzorcach roztworów NaF o stężeniach 0,1; $1 ; 10 \mathrm{mg} \cdot \mathrm{kg}^{-1}$ (Orion, USA).

\section{Opracowanie statystyczne}

Opracowanie statystyczne wykonane z użyciem programu Statistica 10.0 oraz programu Microsoft Excel 2007 obejmowało ustalenie średniego stężenia fluorków w kościach u badanych gatunków ssaków. Obliczono średnią ary tmetyczną (AM), odchylenie standardowe (SD), medianę (Med) i procentowy współczynnik zmienności (CV). Zgodność rozkładów stężeń fluorków sprawdzono za pomocą testu Kołmogorowa-Smirnowa z poprawką Lillieforsa. Do porównań średnich wykorzystano testy nieparametryczne Kruskala-Willisa i U Manna-Whitneya. W ustaleniu korelacji między stężeniem fluorków a wiekiem osobniczym posłużono się współczynnikiem korelacji rang Spearmana. Wszelkie porównania przeprowadzono tylko dla grup organizmów o liczebności $n \geq 4$.

\section{WYNIKI}

Wszystkie wyniki przedstawiono w przeliczeniu na suchą masę (s.m.). W tabeli 4 zamieszczono podstawowe statystyki dotyczące stężenia fluorków w materiale kostnym człowieka, psa, lisa i jenota.

\section{Stężenie fluorków w kościach człowieka}

Różnicę istotną statystycznie stwierdzono między mężczyznami z obu grup wiekowych Hs1 i Hs2 ( $U=5 ; p<0,03)$, przy czym stężenie fluorków u mężczyzn z grupy Hs1 było o 54\% większe w porównaniu do grupy mężczyzn Hs2 (tab. 4). Ponadto, istotną statystycznie różnicę stwierdzono między kobietami i mężczyznami reprezentującymi grupę wiekową Hs2 (U = 12; $\mathrm{p}<0,02$ ). Średnie stężenie fluorków u kobiet powyżej 65. r.ż. było o 51\% większe w porównaniu do mężczyzn w wieku powyżej 65 lat (tab. 4). Badane kości pochodziły od pacjentów, których średnia wieku wynosiła 67 lat (zakres 32-82 lat). Nie potwierdzono istnienia korelacji między stężeniem fluorków w kościach a wiekiem pacjentów (współczynnik korelacji rang Spearmana $r=-0,003 ; p<0,05$ ).

W celu sprawdzenia, czy istnieją różnice między stężeniami fluorków w kościach pochodzących od mieszkańców Szczecina ( $\mathrm{n}=26)$, w którym w latach 90. XX w. prowadzono fluoryzację wody, a w kościach uzyskanych od 10 osób z pozostałych miejscowości województwa zachodniopomorskiego, przeprowadzono odpowiednie porównania. Nie odnotowano istotnych statystycznie różnic w tym zakresie.

Testem Kruskala-Wallisa sprawdzono, czy istnieją statystycznie potwierdzone różnice między stężeniami fluorków w kościach osób z chorobą zwyrodnieniową stawów bez względu na współtowarzyszącą osteoporozę, chorobą zwyrodnieniową stawów ze współistniejącą osteoporozą oraz chorobą zwyrodnieniową stawów bez osteoporozy. W powyższych zakresach nie odnotowano istotnych statystycznie różnic.

\section{Stężenie fluorków w kościach psa}

Ze względu na niewielką liczbę danych dla samców i samic w grupie C.l.f.1 $(\mathrm{n}<4)$ nie przeprowadzono podziału ze względu na płeć (tab. 4). Nie stwierdzono istotnych statystycznie różnic między stężeniami fluorków w kościach samic i samców z grupy C.l.f.2 oraz między wszystkimi samicami (C.l.f.1 + C.l.f.2) i wszystkimi samcami (C.l.f.1 + C.l.f.2).

Testem Kruskala-Wallisa $(\mathrm{H}=11 ; \mathrm{p}<0,003)$ wykazano, że istnieje zróżnicowanie w stężeniu fluorków między grupami wiekowymi psów (bez uwzględnienia ich płci). Jednodniowe szczenięta mają wyraźnie mniejsze stężenie fluorków w kościach niż psy z grupy C.l.f.2, co potwierdzono za pomocą testu U Manna-Whitneya ( $U$ = 57; p < 0,003). Różnica istotna statystycznie zaistniała również między grupami C.l.f.1 i C.l.f.2 
TABELA 4. Stężenie fluorków w kościach człowieka, psa, lisa i jenota z uwzględnieniem płci i wieku

\begin{tabular}{|c|c|c|c|c|c|}
\hline \multirow{2}{*}{ Gatunek } & \multirow{2}{*}{ Płeć, kategoria wiekowa i liczebność } & \multicolumn{4}{|c|}{ Stężenie fluorków (mg·kg-1 s.m.) } \\
\hline & & $\mathrm{AM} \pm \mathrm{SD}$ & mediana & min.-maks. & CV \\
\hline \multirow{9}{*}{$\begin{array}{l}\text { Człowiek } \\
\text { (Homo } \\
\text { sapiens) }\end{array}$} & kobiety, Hs1 $(n=6)$ & $275,1 \pm 281,1$ & 189,5 & $61,7-774,6$ & 102,2 \\
\hline & kobiety, Hs2 (n = 17) & $525,7 \pm 327,5$ & 469,2 & $54,3-1488,8$ & 62,3 \\
\hline & kobiety, Hs1 + Hs2 (n = 23) & $460,3 \pm 329,6$ & 443,3 & $54,3-1488,8$ & 71,6 \\
\hline & mężczyźni, Hs1 (n = 8) & $551,8 \pm 234,1$ & 479,4 & $245,8-926,2$ & 42,4 \\
\hline & mężczyźni, Hs2 (n = 5) & $268,2 \pm 123,6$ & 310,0 & $66,8-385,6$ & 46,1 \\
\hline & mężczyźni, Hs1 + Hs2 (n = 13) & $442,7 \pm 240,2$ & 385,6 & $66,8-926,2$ & 54,3 \\
\hline & $\mathrm{Hs} 1, \mathrm{~K}+\mathrm{M}(\mathrm{n}=14)$ & $433,2 \pm 283,0$ & 408,8 & $61,7-926,2$ & 65,3 \\
\hline & $\mathrm{Hs} 2, \mathrm{~K}+\mathrm{M}(\mathrm{n}=22)$ & $467,2 \pm 311,2$ & 442,0 & $54,3-1488,8$ & 66,6 \\
\hline & wszystkie osoby $(n=36)$ & $453,9 \pm 296,9$ & 442,0 & $54,3-1488,8$ & 65,4 \\
\hline \multirow{11}{*}{$\begin{array}{l}\text { Pies } \\
\text { (Canis lupus } f \text {. } \\
\text { familiaris) }\end{array}$} & samica, C.l.f.1 $(n=1)$ & 201,6 & - & - & - \\
\hline & samice, C.l.f.2 $(n=12)$ & $491,2 \pm 294,2$ & 466,7 & $111,9-942,5$ & 59,8 \\
\hline & samice, C.l.f.1 + C.l.f.2 $(n=13)$ & $469,0 \pm 292,9$ & 457,3 & $111,9-942,5$ & 62,4 \\
\hline & samce, C.I.f.1 $(n=3)$ & $284,0 \pm 204,0$ & 290,4 & $76,9-484,7$ & 71,8 \\
\hline & samce, C.l.f.2 $(n=16)$ & $564,1 \pm 199,3$ & 538,6 & $134,5-959,9$ & 35,3 \\
\hline & samce, C.I.f.1 + C.I.f.2 (n = 19) & $519,9 \pm 220,8$ & 512,5 & $76,9-959,9$ & 42,46 \\
\hline & C.l.f.o, $F+M(n=11)$ & $313,11 \pm 48,04$ & 317,6 & $229,3-383,7$ & 15,3 \\
\hline & C.l.f.1, F + M (n= 4) & $263,4 \pm 171,6$ & 246,0 & $76,9-484,7$ & 65,1 \\
\hline & C.l.f.2, F + M $(n=28)$ & $532,9 \pm 242,2$ & 518,6 & $111,9-959,9$ & 45,4 \\
\hline & C.l.f.1 + C.l.f.2 $(n=32)$ & $499,2 \pm 249,3$ & 491,3 & $76,9-959,9$ & 49,9 \\
\hline & C.l.f. $0+$ C.l.f.1 + C.l.f.2 $(n=43)$ & $451,6 \pm 230,6$ & 443,4 & $76,9-959,9$ & 51,1 \\
\hline \multirow{9}{*}{$\begin{array}{l}\text { Lis } \\
\text { (Vulpes } \\
\text { vulpes) }\end{array}$} & samice, imm $(n=10)$ & $643,0 \pm 316,0$ & 581,1 & $175,9-1105,9$ & 49,14 \\
\hline & samice, ad $(n=7)$ & $523,9 \pm 269,8$ & 422,2 & $329,6-1062,6$ & 51,51 \\
\hline & samice, imm + ad $(n=17)$ & $593,9 \pm 295,2$ & 542,7 & $175,9-1105,9$ & 49,7 \\
\hline & samce, imm $(n=6)$ & $776,8 \pm 234,0$ & 772,0 & $500,2-1182,7$ & 30,12 \\
\hline & samce, ad $(n=9)$ & $986,1 \pm 1036,0$ & 741,9 & $290,1-3668,1$ & 105,0 \\
\hline & samce, imm + ad (n=15) & $902,4 \pm 802,4$ & 752,8 & $290,1-3668,1$ & 88,9 \\
\hline & młode, $F+M(n=16)$ & $693,2 \pm 269,8$ & 681,2 & $329,6-1062,6$ & 51,51 \\
\hline & doroste, $F+M(n=16)$ & $783,9 \pm 810,8$ & 536,5 & $290,1-3668,1$ & 103,4 \\
\hline & wszystkie osobniki $(n=32)$ & $738,5 \pm 600,1$ & 607,9 & $175,9-3668,1$ & 81,3 \\
\hline \multirow{9}{*}{$\begin{array}{l}\text { Jenot } \\
\text { (Nyctereutes } \\
\text { procynoides) }\end{array}$} & samice, imm $(n=4)$ & $310,8 \pm 215,3$ & 280,9 & $83,7-598,0$ & 69,3 \\
\hline & samice, ad $(n=4)$ & $848,3 \pm 348,7$ & 920,2 & $362,4-1190,3$ & 41,1 \\
\hline & samice, imm + ad $(n=8)$ & $579,6 \pm 67,8$ & 480,2 & $83,7-1190,3$ & 67,8 \\
\hline & samce, imm $(n=4)$ & $330,7 \pm 163,9$ & 363,9 & $103,2-492$ & 49,6 \\
\hline & samce, ad $(n=6)$ & $346,7 \pm 157,9$ & 336,2 & $171,8-598,0$ & 45,5 \\
\hline & samce, imm + ad $(n=10)$ & $340,3 \pm 151,2$ & 363,9 & $103,2-598$ & 44,4 \\
\hline & mtode, $F+M(n=8)$ & $320,8 \pm 177,4$ & 333,8 & $83,7-598,0$ & 55,3 \\
\hline & doroste, $F+M(n=10)$ & $547,3 \pm 348,5$ & 411,7 & $171,8-1190,3$ & 63,7 \\
\hline & wszystkie osobniki $(n=18)$ & $446,6 \pm 301,2$ & 371,6 & $83,7-1190,3$ & 67,4 \\
\hline
\end{tabular}

AM - średnia arytmetyczna; SD - odchylenie standardowe; CV - procentowy współczynnik zmienności; Hs1 - osoby <65. r.ż.; Hs2 - osoby >65. r.ż.; K - kobiety; M - mężczyźni; F - samice; M - samce; C.l.f.o - jednodniowe szczenięta psów; C.l.f.1 - psy <2 lat; C.l.f.2 - psy >2 lat; imm - osobniki młode; ad - osobniki dorosłe

( $U$ = 21; p < 0,05), przy czym w starszej grupie psów (>2 lat) stężenie fluorków było o ponad 100\% większe w porównaniu do grupy psów <2 lat (tab. 4). W przypadku psów dysponowano dokładnymi danymi dotyczącymi ich wieku, który zawierał się w przedziale od 1 dnia do 19 lat. Średni wiek badanych osobników wynosił 8 lat. Stwierdzono istotną korelację między stężeniem fluorków w kościach psów a ich wiekiem, przy czym współczynnik korelacji rang Spearmana okazał się wysoce istotny $(r=0,51 ; p<0,001)$.

\section{Stężenie fluorków w kościach lisa}

Porównania przeprowadzone za pomocą testu U MannaWhitneya nie wykazały istotnych statystycznie różnic między stężeniem $\mathrm{F}^{-} \mathrm{w}$ kościach samic i samców w żadnej z grup wiekowych. Nie odnotowano pod tym względem różnic także wtedy, gdy porównywano wszystkie osobniki młode $(\mathrm{F}+\mathrm{M})$ i dorosłe $(\mathrm{F}+\mathrm{M})$, jak również wszystkie samice (immaturus $-\mathrm{imm}+$ adultus - ad) i samce (imm + ad). Podstawowe statystyki opisowe dotyczące stężenia fluorków w kościach lisa zawarto w tabeli 4. 
Dodatkowo przeprowadzono analizę statystyczną dotyczącą stężenia $\mathrm{F}^{-} \mathrm{w}$ kościach lisów pochodzących z różnych regionów północno-zachodniej Polski. Nie odnotowano istotnych statystycznie różnic w stężeniu fluorków w kościach między grupami złożonymi z osobników immaturus i adultus, zarówno samców, jak i samic, pochodzących ze Szczecina i jego okolic $(\mathrm{n}=10)$ oraz z południowej części województwa zachodniopomorskiego $(n=13)$.

\section{Stężenie fluorków w kościach jenota}

Porównaniami przeprowadzonymi za pomocą testu U Manna-Whitneya nie wykazano istotnych statystycznie różnic między stężeniem $\mathrm{F}^{-}$w kościach samic i samców w żadnej z grup wiekowych. Nie odnotowano pod tym względem różnic, gdy porównywano wszystkie osobniki młode $(\mathrm{F}+\mathrm{M})$ i dorosłe $(\mathrm{F}+\mathrm{M})$, jak również wszystkie samice $(\mathrm{imm}+\mathrm{ad})$ i samce $(\mathrm{imm}+\mathrm{ad})$. Podstawowe statystyki opisowe dotyczące stężenia fluorków w kościach jenota zamieszczono w tabeli 4.

Ponadto przeanalizowano różnice między koncentracjami $\mathrm{F}^{-}$ w kościach osobników pochodzących z województw lubuskiego $(n=14)$ i zachodniopomorskiego $(n=4)$. Uwzględniono w nich podział na grupy płciowe i wiekowe, jednak nie odnotowano w tym zakresie żadnych istotnych statystycznie różnic.

\section{Stężenia fluorków w kościach człowieka i psowatych}

Biorąc pod uwagę mediany stężenia fluorków w kościach dorosłych badanych ssaków, ułożono je w szereg, w kolejności od największej do najmniejszej wartości: lis > pies > człowiek > jenot. Stężenia fluorków w kościach lisa i psa są zbliżone i oscylują wokół wartości $525 \mathrm{mg} \cdot \mathrm{kg}^{-1} \mathrm{~s}$.m. Mediany obliczone dla człowieka i jenota okazały się podobne, ale o ok. 20\% mniejsze w porównaniu do psa i lisa.

Testem Kruskala-Wallisa nie potwierdzono istotnych statystycznie różnic między stężeniami fluorków w kościach człowieka i trzech gatunków psowatych. Ponadto zbadano, czy istnieją różnice między stężeniami fluorków w kościach człowieka i psowatych, przy czym próbki pochodzące od dorosłych psów, lisów i jenotów połączono w jedną grupę $(n=54)$. Za pomocą testu U Manna-Whitneya ujawniono istotną statystycznie różnicę między koncentracją $\mathrm{F}^{-}$w próbkach kostnych człowieka i pochodzących od wszystkich dorosłych psowatych ( $U$ = 731; $\mathrm{p}<0,05)$. Mediana stężenia fluorków w próbkach człowieka okazała się o 17\% mniejsza w porównaniu do mediany psowatych, które odpowiednio wynosiły 442,0 i 518,6 mg. $\mathrm{kg}^{-1} \mathrm{~s} . \mathrm{m}$. Zakres stężenia fluorków w całej badanej grupie dorosłych psowatych wynoszący $111-3668 \mathrm{mg} \cdot \mathrm{kg}^{-1} \mathrm{~S}$.m. cechował się znacznie większą rozpiętością w porównaniu do zakresu stężeń fluorków w kościach człowieka (54-1489 mg· $\mathrm{kg}^{-1}$ s.m.).

\section{Stężenia fluorków w kościach psowatych}

Stosowne porównania przeprowadzono między trzema badanymi gatunkami: psem, lisem i jenotem, a w przypadku, gdy było to możliwe (tzn. $n \geq 4$ ), uwzględniono podział na grupy płciowe i wiekowe. Testem Kruskala-Wallisa wykazano, że w grupie trzech gatunków psowatych (gdy nie uwzględniono ich podziału na płeć i wiek) istnieją istotne statystycznie różnice w stężeniu fluorków w kościach $(\mathrm{H}=8,2 ; \mathrm{p}<0,01)$. Dalsza analiza statystyczna (test U Manna-Whitneya) pozwoliła zidentyfikować różnice między parami porównywanych gatunków.

\section{Pies versus lis}

W przypadku psa $(\mathrm{n}=32)$ i lisa $(\mathrm{n}=32)$ nie odnotowano istotnej statystycznie różnicy między średnimi wartościami stężenia fluorków w ich próbkach kostnych. Ponadto nie stwierdzono istotnych różnic w wyodrębnionych grupach: młodych samic (imm), dorosłych samic (ad), wszystkich samic (imm + ad), młodych samców (imm), dorosłych samców (ad), wszystkich samców (imm + ad) i wszystkich dorosłych osobników $(\mathrm{F}+\mathrm{M})$. Natomiast wyraźnie różniły się stężeniem fluorków w kościach młode psy i lisy $(U=6 ; \mathrm{p}<0,02)$. U młodych psów $(\mathrm{n}=4)$ mediana stężenia fluorków okazała się prawie o 180\% mniejsza w porównaniu do młodych lisów $(\mathrm{n}=16)$.

\section{Pies versus jenot}

Pod względem zawartości fluorków analizowane próbki kostne psa $(n=32)$ i jenota $(n=18)$ nie różniły się między sobą. Nie stwierdzono także istotnych statystycznie różnic w obrębie żadnej z wyodrębnionych grup płciowych i wiekowych.

\section{Pies versus dzikie psowate}

W przypadku psa, oprócz porównań tego gatunku oddzielnie z lisem i jenotem, dokonano również analizy dotyczącej stężenia fluorków w kościach tego udomowionego ssaka w odniesieniu do średniej wartości stężenia obliczonej dla połączonych próbek lisa i jenota. Mediana dla próbek kostnych uzyskanych od dzikich psowatych ( $\mathrm{n}=50, \mathrm{w}$ tym 32 pochodzących od lisa i 18 od jenota) wynosiła 535,4 mg.kg-1 s.m. (AM \pm SD, 633,4 $\pm 528,5$ ) i jej wartość nie różniła się istotnie od obliczonej dla psa $(\mathrm{imm}+\mathrm{ad})$, która nieco przekraczała $440 \mathrm{mg} \cdot \mathrm{kg}^{-1} \mathrm{~s} . \mathrm{m}$.

Nie stwierdzono także istotnych różnic między grupami płciowymi psa i dzikich psowatych, jednakże istotną statystycznie różnicę odnotowano między młodymi osobnikami psa (n=4) i młodymi osobnikami dzikich psowatych ( $\mathrm{n}=24)$, co potwierdzono za pomocą testu U Manna-Whitneya $(U=17 ; p<0,05)$. Mediana stężenia fluorków w kościach psów w wieku $<2$ lat wynosiła $246,0 \mathrm{mg} \cdot \mathrm{kg}^{-1} \mathrm{~s}$.m. i okazała się ponad 2,2-krotnie mniejsza w porównaniu do mediany obliczonej dla młodych dziko żyjących psowatych (547,6 mg. $\mathrm{kg}^{-1}$ s.m.).

\section{Lis versus jenot}

Porównując wszystkie badane osobniki lisa $(n=32)$ i jenota ( $\mathrm{n}=18$ ), stwierdzono, że różniły się one stężeniami fluorków w próbkach kostnych $(\mathrm{U}=161 ; \mathrm{p}<0,01)$. U lisa stężenie fluorków okazało się prawie o $64 \%$ większe niż u jenota (odpowiednie mediany wynosiły 607,9 i $371,6 \mathrm{mg} \cdot \mathrm{kg}^{-1}$ s.m.). Stosowne porównania przeprowadzono również między analogicznymi grupami - płciowymi i wiekowymi: młodymi samicami (imm), dorosłymi samicami (ad) i wszystkimi samicami (imm + ad), młodymi samcami (imm), dorosłymi samcami (ad) oraz wszystkimi samcami (imm + ad). Statystycznie istotne różnice zaznaczyły się między wszystkimi samcami (imm + ad) lisa i jenota. 
Mediana stężenia fluorków w próbkach kostnych wszystkich samców lisa ( $\mathrm{n}=15)$ wynosiła $752 \mathrm{mg} \cdot \mathrm{kg}^{-1} \mathrm{~s} . \mathrm{m}$. i była ponad 2-krotnie większa niż 363,9 mg.kg-1 s.m. w próbkach uzyskanych od samców jenota $(\mathrm{n}=10)$, a istotność różnicy potwierdzono testem U Manna-Whitneya ( $\mathrm{U}=15 ; \mathrm{p}<0,001)$.

Wyraźne różnice $(U=8 ; p<0,03)$ zaznaczyły się również między młodymi samcami lisa $(n=6)$ i jenota $(n=4)$, a mediany stężenia fluorków w ich kościach wynosiły odpowiednio 772,0 i 363,9 mg. $\mathrm{kg}^{-1}$ s.m. W grupie dorosłych samców także odnotowano istotną statystycznie różnicę $(U=0 ; p<0,01)$, przy czym dorosłe samce lisa $(n=9)$ w porównaniu do jenota $(n=6)$ miały ponad 2-krotnie większe stężenie fluorków w kościach (odpowiednio 741,9 i 336,2 mg. $\mathrm{kg}^{-1}$ s.m.).

Ponadto gdy porównano ze sobą wszystkie dorosłe osobniki (łącznie samice i samce) lisa $(n=16)$ i jenota $(n=10)$, to okazało się, że istotnie różniły się one między sobą koncentracją $\mathrm{F}^{-} \mathrm{w}$ kościach $(\mathrm{U}=16 ; \mathrm{p}<0,004)$. Wartości mediany stężenia fluorków wynosiły dla dorosłych osobników tych gatunków odpowiednio 536,5 i 411,7 mg. $\mathrm{kg}^{-1}$ s.m.

\section{DYSKUSJA}

W badaniach ekotoksykologicznych, których jednym z celów jest pośrednia ocena zanieczyszczenia środowiska różnymi substancjami, w tym związkami fluoru, wykorzystuje się oznaczenie ich stężeń w organizmach żywych. Koncentrację szkodliwych substancji określa się głównie w narządach odpowiedzialnych za proces detoksykacji - w wątrobie oraz nerkach ptaków i ssaków, jednakże niektóre z nich, w tym związki fluoru, wraz z upływem czasu w zwiększonych ilościach gromadzą się w silnie zmineralizowanych tkankach. Dlatego od kilkudziesięciu lat do badań tego typu wykorzystuje się tkankę kostną, co umożliwia ocenę długotrwałego zanieczyszczenia środowiska fluorkami [5].

Związki fluoru w zależności od stężenia mogą oddziaływać na człowieka i inne kręgowce umiarkowanie korzystnie lub toksycznie. Do biomonitoringu zagrożeń ekologicznych związkami fluoru wykorzystuje się wiele gatunków ssaków, a spośród udomowionych m.in. owcę, bydło i konia, natomiast z grupy dziko żyjących: sarnę, jelenia, dzika, ryjówkę, kreta, norkę amerykańską i mysz leśną $[5,6,7,8,9,10,11,12]$.

Po wnikliwym przeglądzie dostępnego piśmiennictwa naukowego z tego zakresu można stwierdzić, że stężenie fluorków najczęściej badane jest w kościach i zębach ssaków kopytnych oraz zwierząt laboratoryjnych. Liczne są także prace dotyczące stężenia tego pierwiastka w kościach ludzkich $[13,14,15,16,17,18]$. Dużo mniej publikacji poświęconych jest stężeniu fluorków w utworach kostnych psowatych, w tym psa i lisa [1, 2, 19, 20, 21, 22, 23]. Wśród przeanalizowanych publikacji, w których obiektami badań były psowate, nie znaleziono ani jednej pracy dotyczącej stężenia fluorków w kościach jenota, co wskazuje, że gatunek ten dotychczas nie był wykorzystywany w bioindykacji zanieczyszczenia środowiska fluorkami. Ponadto sporadyczne są doniesienia na temat międzygatunkowych porównań dotyczących stężenia fluorków w kościach człowieka oraz dużych i średniej wielkości ssaków [24, 25, 26]. Jedynie Epker w swoich badaniach dokonał porównania stężenia $\mathrm{F}^{-} \mathrm{w}$ kościach człowieka i psa [27]. W dostępnym piśmiennictwie nie znaleziono publikacji dotyczącej porównań stężenia fluorków między przedstawicielami podrodziny Canidae, dlatego przedstawione wyniki można uznać za istotne uzupełnienie wiedzy w tym zakresie.

W ekotoksykologicznych studiach porównawczych dotyczących fluorków przedmiotem analiz są przede wszystkim silnie zmineralizowane tkanki uzyskiwane od średniej i dużej wielkości dziko żyjących ssaków kopytnych (głównie łownych: sarny, jelenia, łosia i dzika), a rzadziej udomowionych (owcy, bydła, konia i psa), jednakże niewiele jest prac z tego zakresu dotyczących porównań między człowiekiem i innymi długowiecznymi ssakami. Zawierta i wsp. badali stężenie $\mathrm{F}^{-} \mathrm{w}$ kościach człowieka i jelenia zamieszkujących obszary północno-zachodniej Polski o małym i dużym zanieczyszczeniu powietrza fluorkami [24]. Na terenie o małym zanieczyszczeniu koncentracja tych związków w kościach jelenia była o 22\% mniejsza niż w kościach człowieka ( $p<0,05)$, a na terenie bardziej zanieczyszczonym różnica ta była zdecydowanie mniejsza ( $\mathrm{p}<0,05)$. W kościach jelenia stężenie $\mathrm{F}^{-}$było tam zaledwie o 8\% większe niż w kościach człowieka. Różnice w stężeniu $\mathrm{F}^{-} \mathrm{w}$ kościach obu gatunków mogły być związane z odmienną dietą oraz budową tkanki kostnej. Jeleń jest zdeterminowanym roślinożercą, a człowiek należy do grupy ssaków wszystkożernych. Ponadto, w kościach jelenia występuje istota zbita wraz ze znacznym udziałem tkanki splotowatej [28]. Charakteryzuje się ona małą wytrzymałością mechaniczną (podobnie jak kość ze zmianami o charakterze osteoporozy) i w większym stopniu kumuluje fluorki [18]. Natomiast w kościach długich człowieka dominuje istota zbita w trzonie, a istota gąbczasta w nasadach kości. U człowieka tkanka splotowata fizjologicznie występuje tylko w błędniku kostnym ucha i wyrostkach zębodołowych [28]. W związku z tym wydaje się, że jeleniowate nie są zbyt dobrymi organizmami do porównań stężeń fluorków w tkance kostnej w stosunku do człowieka. Z tego powodu poszukuje się innych gatunków ssaków, bardziej podobnych do człowieka pod względem budowy i metabolizmu tkanki kostnej. Jak wynika z badań Hillera i Bella [28], tkanka kostna psowatych jest zbliżona budową do tkanki kostnej człowieka, a różnice dotyczą głównie wielkości oraz ilości kanałów i systemów Haversa.

Na podstawie porównań przeprowadzonych w niniejszej pracy wydaje się, że niektóre ssaki drapieżne z rodziny psowatych mogą być z powodzeniem traktowane jako organizmy biowskaźnikowe i modelowe w studiach, w tym porównawczych, nad zanieczyszczeniem środowiska fluorkami. Dotychczas były one rzadko wykorzystywane do tego typu badań, a dane z tego zakresu są niepełne. Wprawdzie tempo metabolizmu psowatych jest szybsze w porównaniu do metabolizmu człowieka, to jednak, biorąc pod uwagę ich długowieczność, można uzyskać znacznie bardziej adekwatne dane porównawcze w stosunku do człowieka niż w przypadku krótko żyjących gryzoni (szczura i myszy) czy zdeterminowanych roślinożernych ssaków średniej i dużej wielkości [29]. Ponadto 
wiele innych cech predysponuje psowate do roli dobrych biologicznych wskaźników zanieczyszczenia środowiska fluorkami. Są one gatunkami pospolitymi o dużym zasięgu występowania, zamieszkującymi to samo środowisko przez cały rok, zajmującymi stałą pozycję w łańcuchu troficznym, a ich populacje są stabilne i przejawiają tendencje wzrostowe.

W prezentowanych badaniach stwierdzono znaczne podobieństwo w stężeniu $\mathrm{F}^{-} \mathrm{w}$ kościach człowieka i dorosłych osobników jenota (odpowiednio 442 i $412 \mathrm{mg} \cdot \mathrm{kg}^{-1}$ s.m.), a także dorosłych psów i lisów (odpowiednio 519 i $536 \mathrm{mg} \cdot \mathrm{kg}^{-1}$ s.m.). Podobne wartości stężenia fluorków w kościach lisa i psa mogą świadczyć o tym, że zarówno silnie zmodyfikowana przez człowieka dieta psa, jak i pokarm zdobywany przez lisa na obszarach o umiarkowanym zanieczyszczeniu środowiska fluorkami mogą mieć istotny wpływ na ich kumulację w kościach tych zwierząt. W niniejszych badaniach odnotowano istotną statystycznie różnicę między koncentracją fluorków w próbkach kostnych pochodzących od młodych psów i lisów, jednakże w tym przypadku mogła na to wpłynąć mała liczebność psów $\mathrm{z}$ tej grupy wiekowej $(\mathrm{n}=4) \mathrm{w}$ porównaniu do 4-krotnie większej grupy młodych lisów $(n=16)$.

Nie odnotowano istotnych statystycznie różnic między stężeniami fluorków u człowieka i poszczególnych gatunków psowatych, jednak połączenie wszystkich psowatych pochodzących z północno-zachodniej Polski w jedną grupę i porównanie jej z człowiekiem ujawniło istnienie potwierdzonej statystycznie różnicy w omawianym zakresie. Stężenie fluorków u człowieka było o 17\% mniejsze w porównaniu do psowatych.

W niniejszej rozprawie pierwszy raz przeanalizowano podobieństwa i różnice dotyczące stężenia fluorków w kościach człowieka i psa bytujących w zbliżonych warunkach. Wykazano bliską istotności statystycznej różnicę w stężeniu fluorków w kościach człowieka i dorosłych psów, a wartości stężenia $\mathrm{F}^{-}$wynosiły odpowiednio 442 i $519 \mathrm{mg} \cdot \mathrm{kg}^{-1} \mathrm{~s} . \mathrm{m}$. Do powstania tej różnicy mogła przyczynić się dieta psów, która jest stosunkowo bogata we fluorki.

W przypadku człowieka i dorosłych osobników lisa wykazano bliską istotności statystycznej różnicę między wartościami stężenia fluorków w ich kościach. Stężenie $\mathrm{F}^{-} \mathrm{u}$ człowieka było o 21\% mniejsze w porównaniu do lisa. Do większego stężenia fluorków u lisa mógł przyczynić się jeden osobnik (upolowany w okolicach Stargardu Szczecińskiego), u którego wykryto bardzo dużą koncentrację ( $3670 \mathrm{mg} \mathrm{F}^{-} \cdot \mathrm{kg}^{-1}$ s.m.).

Zdecydowanie największą różnicę, potwierdzoną statystycznie, odnotowano między średnimi stężeniami fluorków w kościach lisa i jenota z północno-zachodniej Polski. U lisa wykryto o ponad $60 \%$ większe ich stężenie. Do powstania tej różnicy najprawdopodobniej przyczyniły się odmienny tryb życia i dieta tych zwierząt. Jenot jako jedyny przedstawiciel psowatych zapada w okresową anabiozę, co jest odpowiedzią na niedostateczną podaż pokarmu podczas zimy. Natomiast lis pobiera pokarm przez cały rok, kumulując fluorki w tym czasie.

Biorąc pod uwagę powyższe przesłanki wynikające z prac innych autorów i wyników badań własnych, można uznać, że psowate spełniają kryteria dobrych bioindykatorów zanieczyszczenia środowiska fluorkami, a ich tkanka kostna jest odpowiednim materiałem do porównań ich stężeń z tkanką kostną człowieka.

\section{PODSUMOWANIE I WNIOSKI}

Studia przeprowadzone w Szczecinie są pierwszymi, w których równocześnie przeanalizowano stężenia $\mathrm{F}^{-} \mathrm{w}$ kościach człowieka, psa, lisa i jenota. Dlatego porównania międzygatunkowe w tym zakresie mają charakter unikatowy. Wykonane badania i analiza wyników pozwoliły na sformułowanie poniższych stwierdzeń i wniosków w dwóch aspektach: wewnątrzgatunkowym i międzygatunkowym.

\section{Analiza wewnątrzgatunkowa}

\section{Cztowiek (Homo sapiens)}

1. U człowieka największe średnie stężenie $\mathrm{F}^{-}$stwierdzono w próbkach kości pobranych od mężczyzn w wieku >65. lat, a najmniejsze u kobiet w wieku poniżej 65 lat. Istotne różnice wykryto między średnimi koncentracjami $\mathrm{F}^{-} \mathrm{w}$ kościach mężczyzn z porównywanych kategorii wiekowych (poniżej 65 i powyżej 65 lat) - większe było u starszych mężczyzn $(\mathrm{p}<0,03)$, jednak w grupie wszystkich badanych pacjentów nie stwierdzono korelacji między stężeniem $\mathrm{F}^{-} \mathrm{w}$ kościach a ich wiekiem. Dzięki analizie uwzględniającej płeć wykazano, że większe średnie stężenie $\mathrm{F}^{-} \mathrm{w}$ kościach występowało u kobiet w wieku powyżej 65 lat w porównaniu do mężczyzn $\mathrm{z}$ analogicznej grupy wiekowej $(\mathrm{p}<0,02)$.

2. Nie wykryto istotnej różnicy $\mathrm{w}$ stężeniu $\mathrm{F}^{-}$między próbkami uzyskanymi z kości mieszkańców Szczecina (gdzie fluorkowano wodę do połowy lat 90.) i innych miejscowości województwa zachodniopomorskiego.

3. Nie odnotowano istotnych różnic między stężeniami $\mathrm{F}^{-}$ w próbkach uzyskanych od pacjentów z różnymi chorobami układu kostno-stawowego, jednakże przeprowadzone porównania własnych wyników z analogicznymi danymi uzyskanymi z piśmiennictwa, które dotyczyły osób badanych w Szczecinie w latach 90., pozwoliły wykazać, że kości pacjentów hospitalizowanych w szczecińskim szpitalu w 2009 r. cechowały się w stosunku do nich wyraźnie mniejszym stężeniem $\mathrm{F}^{-}$(od 35\% do 79\%, zależnie od uwzględnionego w porównaniu schorzenia kości). Na zaobserwowane różnice mogło mieć wpływ zaprzestanie sztucznego fluorkowania wody w Szczecinie oraz modernizacja zakładów chemicznych w Policach (zapoczątkowana w połowie lat 90.), która ograniczyła emisję fluorków do środowiska.

\section{Pies (Canis lupus $f$. familiaris)}

1. W przypadku psa próbki podzielono na trzy grupy uzyskane od jednodniowych szczeniąt, młodych psów (poniżej 2 lat) i starszych (powyżej 2 lat). W kościach szczecińskich psów największe średnie stężenie $\mathrm{F}^{-}$stwierdzono w grupie dorosłych samców, a najmniejsze u młodych psów. Starsze psy miały istotnie większą koncentrację $\mathrm{F}^{-}$niż jednodniowe 
szczenięta i młode osobniki. Odnotowano istotną korelację między stężeniem $\mathrm{F}^{-}$w kościach psów a ich wiekiem $(\mathrm{p}<0,001)$. Między dorosłymi samicami i samcami nie stwierdzono istotnej różnicy w badanym zakresie.

2. Uzyskane własne wyniki nie odbiegają od analogicznych podawanych przez innych autorów i okazały się typowe dla stężenia $\mathrm{F}^{-}$w kościach psów niesuplementowanych fluorkami.

\section{Lis (Vulpes vulpes)}

Próbki kostne lisa podzielono na dwie grupy - uzyskane od młodych osobników (<2 lat) i starszych. W kościach lisa największą średnią koncentrację $\mathrm{F}^{-}$stwierdzono w grupie młodych samców, a najmniejszą u dorosłych samic. Nie odnotowano istotnych różnic w stężeniach $\mathrm{F}^{-} \mathrm{w}$ kościach lisów, gdy w porównaniach uwzględniono ich wiek, płeć i pochodzenie zwierząt.

\section{Jenot (Nyctereutes procyonoides)}

Próbki kostne jenota podzielono na dwie grupy - uzyskane od młodych i starszych osobników. U tego gatunku psowatego największe średnie stężenie $\mathrm{F}^{-} \mathrm{w}$ kościach stwierdzono u osobników dorosłych, a najmniejsze u młodych samic. Nie wykryto istotnych różnic między stężeniami $\mathrm{F}^{-} \mathrm{w}$ badanych próbkach, gdy w analizie uwzględniono kategorię wiekową, płeć oraz obszar, z którego pochodziły jenoty.

\section{Analiza międzygatunkowa}

\section{Porównania między człowiekiem a psowatymi}

1. W tej części analizy międzygatunkowej uwzględniono tylko próbki pochodzące od dorosłych osobników. Porównania międzygatunkowe wykazały, że spośród próbek kostnych uzyskanych od 4 gatunków ssaków zamieszkujących północno-zachodnią Polskę największe średnie stężenie $\mathrm{F}^{-}$występowało u lisa, a najmniejsze u jenota. Okazało się, że mediany ich koncentracji były najbardziej zbliżone w przypadku człowieka i jenota, a różne w przypadku człowieka i psa oraz lisa.

2. Nie odnotowano istotnych różnic między stężeniem $\mathrm{F}^{-}$ w kościach pobranych od człowieka i poszczególnych gatunków psowatych, jednak gdy połączono wszystkie dane dotyczące psowatych w jedną grupę, wówczas w badanym zakresie wystąpiła istotna różnica między człowiekiem a analizowanymi gatunkami zwierząt, natomiast średnie stężenie $\mathrm{F}^{-}$w próbkach kostnych człowieka okazało się mniejsze w porównaniu do psowatych $(\mathrm{p}<0,05)$.

\section{Porównania między psowatymi}

1. Porównania między różnymi gatunkami psowatych przeprowadzono oddzielnie dla osobników młodych i dorosłych. Między psem i lisem istotną różnicę w ich średnich stężeniach $\mathrm{F}^{-} \mathrm{w}$ kościach odnotowano jedynie w odniesieniu do młodych osobników ( $\mathrm{p}<0,02)$, a koncentracja $\mathrm{F}^{-}$była wyraźnie większa u lisa niż psa. Potwierdzonych statystycznie różnic nie wykryto w badanym zakresie między psem i jenotem.

2. Analiza porównawcza między psem a dzikimi psowatymi, gdy połączono dane dotyczące lisa i jenota w jedną grupę, wykazała, że tylko między młodymi osobnikami istnieje po- twierdzona statystycznie różnica $(\mathrm{p}<0,05)$, a w próbkach kostnych psa stężenie $\mathrm{F}^{-}$było ponad 2-krotnie mniejsze niż u dzikich psowatych.

3. Najwięcej istotnych różnic odnotowano między stężeniem $\mathrm{F}^{-} \mathrm{w}$ kościach lisa i jenota. Wystąpiły one w przypadkach porównywania: wszystkich osobników $(p<0,01)$, wszystkich dorosłych osobników (łącznie samce i samice, $\mathrm{p}<0,004$ ), wszystkich samców $(p<0,001)$, młodych samców $(p<0,03)$ oraz dorosłych samców $(\mathrm{p}<0,01)$. W każdym przypadku większe stężenia $\mathrm{F}^{-}$wykryto w kościach lisa.

\section{Weryfikacja hipotez}

Biorąc pod uwagę uzyskane rezultaty i przeprowadzone analizy porównawcze, przedstawiono wynik weryfikacji postawionych w pracy hipotez badawczych.

1. Pierwsza hipoteza zakładała, że większe stężenie $\mathrm{F}^{-}$będzie występowało u człowieka i psa w porównaniu do dziko żyjących psowatych. Nie została ona potwierdzona, gdyż największą koncentrację $\mathrm{F}^{-}$stwierdzono u lisa, ale jej średnia wartość statystycznie nie różniła się od zanotowanej u człowieka $(\mathrm{p}<0,08)$.

2. Druga hipoteza, w której założono, że kości starszych osobników cechują się większym stężeniem $\mathrm{F}^{-}$, została częściowo potwierdzona. U wszystkich badanych gatunków koncentracja $\mathrm{F}^{-} \mathrm{w}$ próbkach była większa u osobników dorosłych, ale jedynie w przypadku psa potwierdzone zostały statystyczne różnice między starszymi zwierzętami a jednodniowymi szczeniętami oraz młodymi psami (<2 lat).

3. $W$ trzeciej hipotezie przyjęto założenie, że w grupie dorosłych osobników średnie wartości koncentracji $\mathrm{F}^{-}$będą układały się w następujący szereg: człowiek > pies > lis = jenot. Tymczasem uzyskane wyniki dotyczące median mają inny układ: lis > pies > człowiek > jenot.

4. Założenie czwartej hipotezy - udomowione i dziko żyjące psowate są dobrymi bioindykatorami zanieczyszczenia środowiska fluorkami - zostało w pełni udowodnione. Ponadto w pracy wykazano, że środowisko północno-zachodniej Polski jest w zróżnicowanym stopniu zanieczyszczone fluorkami, a dieta badanych psowatych, zwłaszcza znaczny w niej udział pożywienia roślinnego (u jenota), wpływa na zmniejszenie stężenia $\mathrm{F}^{-} \mathrm{w}$ ich kościach.

\section{PIŚMIENNICTWO}

1. Kalisińska E., Palczewska M.: Fluorki w zębach lisa Vulpes vulpes z Pomorza Zachodniego. Ochr Środ Zasobów Nat. 2007, 31, 428-433.

2. Kalisińska E., Palczewska-Komsa M.: Teeth of the red fox Vulpes vulpes (L., 1758) as a bioindicator in studies on fluoride pollution. Acta Theriol (Warsz). 2011, 56, 343-351.

3. Knowlton F., Whittemore S.: Pulp cavity-tooth width ratios from known-age and wild-caught coyotes determined by radiography. Wildl Soc Bull. 2001, 19, 239-244.

4. Canids: Foxes, Wolves, Jackals and Dogs. Status Survey and Conservation Action Plan. Eds: C. Sillero-Zubiri, M. Hoffmann, D.W. Macdonald. IUCN/ SSC Canid Specialist Group, Gland-Cambridge 2004, 1-430.

5. Bezerra de Menezes L.M., Volpato M.C., Rosalen P.L., Cury J.A.: Bone as a biomarker of acute fluoride toxicity. Forensic Sci Int. 2003, 137 (2-3), 209-214. 
6. Ekstrand J., Lange A., Hammarstorm L.: Relationship between plasma, dentin and bone fluoride concentrations in rats following long-term fluoride administration. Acta Pharmacol Toxicol. 1981, 48 (5), 433-437.

7. Speirs R.L.: The relationship between fluoride concentrations in serum and in mineralized tissues in the rat. Arch Oral Biol. 1986, 31 (6), 373-381.

8. Shupe J.L., Larsen A.E., Olson A.E.: Effects of diets containing sodium fluoride on mink. J Wildl Dis. 1987, 23 (4), 606-613.

9. Walton K.C.: Environmental fluoride and fluorosis in mammals. Mam Rev. 1988, 18, 77-90.

10. Whitford G.M., Biles E.D., Birdsong-Whitford N.L.: A comparative study of fluoride pharmacokinetics in five species. J Dent Res. 1991, 70 (6), 948-951.

11. Kierdorf U., Kierdorf H., Erdelen M., Machoy Z.: Mandibular bone fluoride accumulation in wild red deer (Cervus elaphus L.) of known age. Comp Biochem Physiol A Physiol. 1995, 110 (4), 299-302.

12. Gutowska I., Machoy Z., Machaliński B., Chlubek D.: Ocena warunków bytowania zwierzyny płowej z Pomorza Zachodniego i Ziemi Lubuskiej na podstawie zawartości fluorków, wapnia i magnezu w żuchwach i zależności pomiędzy zawartościami pierwiastków w żuchwach zwierząt. Ann Acad Med Stetin. 2004, 50 (Suppl. 1), 42-46.

13. Zipkin I., McClure F.J., Leone N.C., Lee W.A.: Fluoride deposition in human bones after prolonged ingestion of fluoride in drinking water. Public Health Rep. 1958, 73 (8), 732-740.

14. Suzuki Y: The normal levels of fluorine in the bone tissue of Japanese subjects. Tohoku J Exp Med. 1979, 129 (4), 327-336.

15. Alhava E.M., Olkkonen H., Kauranen P., Kari T.: The effect of drinking water fluoridation on the fluoride content, strength and mineral density of human bone. Acta Orthop Scand. 1980, 51 (3), 413-420.

16. Ishiguro K., Nagasaki H., Tsuboi S., Narita N., Kato K., Li J. et al.: Distribution of fluoride in cortical bone of human rib. Calcif Tissue Int. 1993, 52 (4), 278-282.

17. Hać E., Czarnowski W., Gos T., Krechniak J.: Lead and fluoride content in human bone and hair in the Gdańsk region. Sci Total Environ. 1997, 206 (2-3), 249-254.

18. Bohatyrewicz A., Ogoński T., Dąbkowska E., Machoy Z.: Skład mineralny tkanki kostnej blaszkowatej i zbitej u pacjentek ze złamaniem szyjki kości udowej na tle osteoporozy. In: Fluor i biopierwiastki w biologii i medycynie. Eds: T. Ogoński, D. Samujło, Z. Machoy. VIII Sympozjum Fluorowe, 23-24 kwietnia 1998, Szczecin 1998, 70-74.

19. Greenwood D.A., Blayney J.R., Skinsnes O.K., Hodges P.C.: Comparative studies of the feeding of fluorides as they occur in purified bone meal powder, defluorinated phosphate and sodium fluoride, in dogs. J Dent Res. 1946, 25 (5), 311-326.

20. Gardner D.E., Smith F.A., Hodge H.G., Brudevold F., Eldredge D.M.: Distribution of fluoride in the normal dog femur. J Appl Phisiol. 1959, 14 (3), 427-430.

21. Kay C.E., Tourangeau P.C., Gordno C.C.: Fluoride levels in indigenous animals and plants collected from uncontaminated ecosystems. Fluoride. $1975,8,125-133$.

22. Walton K.C.: Fluoride in fox bone near an aluminium reduction plant in Anglesey, Wales and elsewhere in the United Kingdom. Environ Poll Series B Chem Phys. 1984, 7 (4), 273-280.

23. Khandare A.L., Kumar P.U., Lakshmaiah N.: Beneficial effect of tamarind ingestion on fluoride toxicity in dogs. Fluoride. 2000, 33 (1), 33-38.

24. Zawierta J., Chlubek D., Dąbkowska E., Bohatyrewicz A., Wieczorek P., Walat $S$. et al.: Comparison of fluoride concentration in bones of humans and animals inhabiting the region of Western Pomerania and exposed to emissions of fluorine compounds from industrial sources. Environ Sci. 2002, 9 (4), 283-288.

25. Medina N., Douglass C.W., Whitford G.M., Hoover R.N., Fears T.R.: A reproducibility study for a fluoride assay in bone. Cancer Epidemiol Biomarkers Prev. 2006, 15 (5), 1035-1037.

26. Tankersley K.B., Wells D.H.: Further evaluation of fluoride dating by ion selective electrode analysis. North Am Archeol. 2011, 32 (3), 247-265.

27. Epker B.N.: A quantitative histologic study of the effects of fluoride on resorption and formation in animal and human bone. Clin Orthop Relat Res. 1966, 49, 77-88.

28. Hillier M.L., Bell L.S.: Differentiating human bone from animal bone: a review of histological methods. J Forensic Sci. 2007, 52 (2), 249-263.

29. Mcdonald D.W., Reynolds J.C.: Red fox Vulpes vulpes Linnaeus, 1758. In: Canids: foxes, wolves, jackals and dogs. Status survey and conservation action plan. Eds: C. Sillero-Zubiri, M. Hoffmann, D.W. Macdonald. IUCN/ SSC Canid Specialist Group, Gland-Cambridge 2001, 129-136. 